Article

\title{
Traceability System for Improved Utilization of Solid Biofuel from Agricultural Prunings
}

\author{
Techane Bosona ${ }^{1, *(1)}$, Girma Gebresenbet ${ }^{1}$ and Sven-Olof Olsson ${ }^{2}$ \\ 1 Department of Energy and Technology, Swedish University of Agricultural Sciences, P.O. Box 75651 Uppsala, \\ Sweden; girma.gebresenbet@slu.se \\ 2 Mobitron AB, P.O. Box 56146 Huskvarna, Sweden; soo@mobitron.se \\ * Correspondence: techane.bosona@slu.se
}

Received: 8 December 2017; Accepted: 17 January 2018; Published: 23 January 2018

\begin{abstract}
Biomass production and supply for renewable energy generation should be managed well and carried out in a sustainable manner. An effective traceability system (TS) is required to provide sufficient information and assure the quality of the biomass. The objective of this study is to define and develop a TS to assure the pruning biomass quality for the production of solid biofuels and to provide guarantee to the final user that the biomass is in good condition according to recommended quality criteria. It is designed for an agricultural pruning supply chain in which farmers, biomass traders, transporters, and end users are major actors. It is based on the biofuel quality requirements required by final users and other standards such as the new European standards EN 14961-1, EN15234:1-2011, and EN14961-1:2010, which describe solid fuel quality parameters. Traceable quality parameters include origin and source of product, traded form, bale dimension, chips size distribution, moisture content, ash content, and density of biomass. In this TS, a unique product label is introduced and integrated into a smart logistics system (SLS). The TS uses information captured at different stages of the product supply chain. It enables the management of the whole pruning biomass supply chain with the support of a centralized web-based information platform, an integral part of the SLS.
\end{abstract}

Keywords: pruning biomass; solid biofuel; traceability system; smart logistics system; information flow

\section{Introduction}

Reducing the use of fossil fuel enables the reduction of their environmental impact due to related emissions. From 2004 to 2014, the renewable energy produced within EU-28 countries increased by $73.1 \%$ [1]. In relation to this, the European Commission considers biomass as a promising alternative energy source and aims to provide up to $20 \%$ of energy use by biomass energy sources by 2020 [2,3]. Agricultural residues such as fruit tree prunings are among renewable biomass energy sources [4]. If developed effectively, pruning biomass-based energy sources can generate income for farmers and promote the local economy as well as the utilization of renewable energy. Although bioenergy has a high potential of renewable energy for the supply of electricity, heating (or cooling), and transport, biomass production and supply activities should be carried out in a sustainable manner [5]. Specifically, there is limitation in the logistics and product traceability systems (TS) for efficient use of agricultural prunings for energy generation [6]. Therefore, a system that enables the supply of agricultural prunings for energy generation fulfilling the biofuel quality requirements of end users (energy plants) is needed. This also promotes the sustainable use of bioenergy resources. Investigating the sustainability of the production of biodiesel from sunflower in Italy, Spugnoli et al. [7] pointed out that a well-defined traceability system (TS) of raw materials is important to satisfy the environmental criteria adopted by the European Union Renewable Energy Directive 2009/28/EC (RED) to promote a sustainable biofuel supply chain. 
A TS is also a vital tool for supply chain management. Traceability has three major components [8,9]: backward follow-up of products (tracing), forward follow-up of products (tracking), and the product history information associated with the product movement in the supply chain. In this study, the traceability of pruning biomass can be defined as the system that captures, stores, and transmits adequate information about the biomass item at all stages in the biomass supply chain so that the biofuel can be checked for quality, traced upward, and tracked downward in the entire chain.

The biomass should be delivered to the final users in good condition and with the required quality. Product labeling is a means of controlling information flow for quality assurance and it is part of TS. It helps to control the quality associated with the origin and production methods. It strengthens the confidence of the end user on the quality and safety of biofuel products. The label data elements may include $[9,10]$ : trade item number, catch date, expiry date, order identification, dispatch date, batch/lot number, product variety, pack/size, name and address of responsible distributor, and country of origin. Designation of origin and product source is very important in product traceability. The regulation EC No. 510/2006 sets out provisions on agricultural products and foodstuffs from a defined geographical area [11].

An effective TS needs continuous information flow. In this regard, there are two types of traceability information flow models [12].

(i) One step up-one step down flow model: In this case, some information is filtered at each stage, allowing only limited information to follow the product to the next stage.

(ii) Aggregated information flow model: In this case, no information filtering is applied and aggregated information follows the product to the end point. The first option of the information flow model was applied in this study, because some information can be considered optional and be handled only by producers of biomass products.

Traceability technologies play an important role in improving the performance of product traceability efforts. The major available traceability tools include barcodes, radio frequency identification (RFID), and electronic identification (EID) [13-16]. Wireless sensor technologies are attracting attention due to their reduced cost and promising application in many fields including agriculture. For instance, the standardized adoption of Bluetooth, ZigBee, and RFID are becoming promising for applications in fields such as product traceability and quality control [17].

In order to ensure the sustainable production of biomass, there should be clearly defined criteria [18]. In relation to this, there are quality standards developed to promote biomass-based energy use and biofuel quality. For instances, European standards EN 14961-1 (New European Pellets Standard), EN15234:1-2011 (Solid biofuels-Fuel quality assurance), and EN14961-1:2010 (Solid biofuels-Fuel specifications and classes) are relevant standards regarding solid biofuels [19-23]. Some of these quality standards are useful for developing a TS. There are also efforts made to develop certification criteria that take into consideration the sustainability and traceability information fulfilment for biomass and biofuel production and supply [20,24]. However, to the knowledge of the authors, there is no coordinated information flow system that enables one to effectively trace agricultural pruning-based solid biofuels and efficiently manage the pruning biomass production and delivery to end users.

The objective of this study was to define and develop a TS to assure the pruning biomass quality for energy. It includes creating a labeling for prunings biomass. Product labels facilitate product traceability and provide guarantee to the final user and/or logistic operator that the biomass is in good condition. Based on the information on the label, the biomass trading system manager can trace the entire history of the biofuel product along the supply chain. Such traceability information ought be recorded and documented on the web-based information platform which is part of the smart logistics system (SLS), as depicted in Figure 1. The SLS consists of four major components [6]:

(a) Smart Box: this is a sensor unit that measures some parameters of biomass like relative humidity, temperature, and geographic positions; 
(b) On-board control unit: this enables the user to perform route planning and monitor the recordings made by the smart box;

(c) Information platform: this is a centralized platform for performing documentation and data sharing, as well as facilitating biomass trading and management of pruning supply chain and traceability; and

(d) Central control unit: this serves as an interface linking the Information platform and On-board control unit and serves as a point of administration for the whole biomass logistics system [6].

This SLS tool was developed as part of the EuroPruning project and tested in Germany, Spain, and Sweden [25]. The detailed design and evaluation of the SLS has been presented in a separate paper [6]. The TS is integrated into the SLS so that the information documented in the web-based information platform can be used effectively for biofuel product traceability. The TS enables its users to assure the quality of the pruning biomass according to recommended biomass quality criteria for energy production (new European standards EN 14961-1, EN15234:1-2011, and EN14961-1:2010) and the need of local end users.

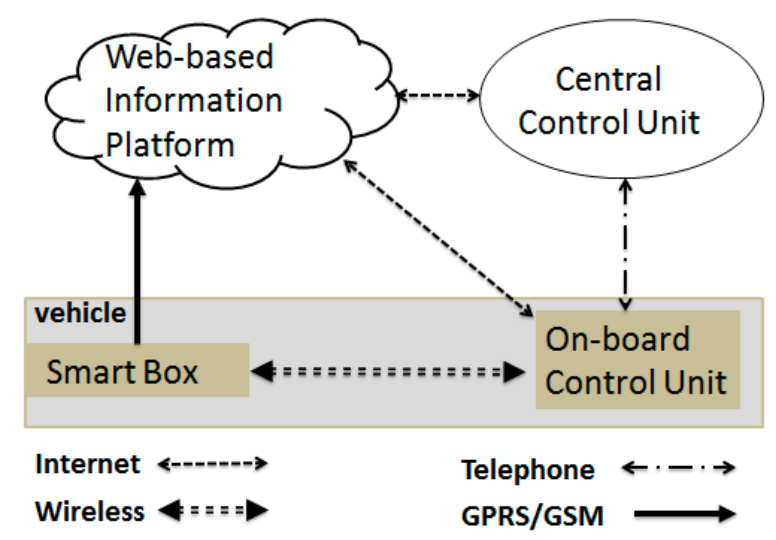

Figure 1. Conceptual representation of a smart logistics system (SLS).

\section{Defining Characteristics of Traceability System}

\subsection{Factors for Determining the Traceability System}

In determining appropriate TS for solid biofuel supply chain, there are factors that need to be defined clearly: name, scope, and objectives of the TS, production rules, product characters, labeling rules, information to be indicated on the label, information to be traced, and traceability technologies. Table 1 defines the key characteristics of this TS.

In general, there are some basic conditions that need to be considered during the design and implementation of a product label [26]:

- The label should have company's name and contact information

- It should use terms that can describe the material under consideration

- It must be visible on the packaging

- Label design must be sync with label material

- The label must have a reference so that the control body can certify the product

- The color, font size, and style of lettering should be determined

- Label size can be determined depending on whether the both sides (front and back) or a single label or multiple labels can be used or not

- The label should have an appropriate shape that can draw attention e.g., rectangle, square, circle, or oval shapes can be used

- The label should have barcodes 
In addition to the general conditions described above, the biomass label should be easily understandable, enabling consumers to utilize energy-efficient biomass; promote the utilization of biomass resources in a more environmental friendly way; provide basic information for decision-makers; include the information most required by customers; and be coherent with existing (and possibly applicable in future) legislation.

Table 1. Description of characteristics of the created traceability system (TS).

\begin{tabular}{|c|c|}
\hline Character & Description \\
\hline System & EuroPruning traceability system \\
\hline Label name & EuroPruning Label \\
\hline Objective of labeling & $\begin{array}{l}\text { It is intended to create a label for pruning biomass feedstock capable of ensuring the } \\
\text { traceability of pruning quality parameters and guaranteeing to the final user and/or logistic } \\
\text { operator that the biomass is in good condition according to defined requirements within the } \\
\text { scope of this TS. }\end{array}$ \\
\hline Scope & $\begin{array}{l}\text { This document explains the procedures and contents of the new label which is designed } \\
\text { within this project framework. It is based on the biomass quality requirements described in } \\
\text { Section 2.6. These quality parameters are identified based on objectives of the project and } \\
\text { standards describing solid fuel quality parameters such as new European standards EN } \\
\text { 14961-1, EN15234:1-2011, and EN14961-1:2010 [21-23]. This labeling system does not include } \\
\text { the sustainability parameters such as greenhouse gas emission (GHG) and energy use in } \\
\text { relation to the pruning biomass supply chain. }\end{array}$ \\
\hline Production rules & $\begin{array}{l}\text { Major production and processing rules concerning the pruning biomass under consideration } \\
\text { should be identified (for instance whether products are from irrigated farm or not, whether it } \\
\text { is processed in the form of bales or chips, and the recommended sizes of bales and chips). }\end{array}$ \\
\hline $\begin{array}{l}\text { Designation of origin } \\
\text { and product source }\end{array}$ & $\begin{array}{l}\text { Country or area of origin is one of the pieces of information required in a traceability system. } \\
\text { The name of farm and country, geographical location, and associated trade contract should be } \\
\text { known, as well as the source of product (e.g., wood from vineyards). This identification is } \\
\text { based on classification according to standard EN14961-1:2010 [23]. }\end{array}$ \\
\hline Product character & $\begin{array}{l}\text { Some key characters of the product have to be included e.g., dimensions of bale (bale size), } \\
\text { particle size distribution of chips, and ash content. }\end{array}$ \\
\hline $\begin{array}{l}\text { Traceability } \\
\text { technology }\end{array}$ & $\begin{array}{l}\text { A quick response (QR) code is implemented in this TS. This traceability system is part of a } \\
\text { smart logistics tool developed to optimize the logistics of the whole supply chain management } \\
\text { of the pruning biomass supply chain. This smart tool uses a scanner of QR codes and other } \\
\text { parts such as a General Packet Radio service [GPRS] wireless system and a unique } \\
\text { website-based application platform [6] for the continuity of information flow. The actors } \\
\text { (e.g., farmer) who sell their products register all required product quality information via the } \\
\text { platform, which generates the QR code, and prints the label with the QR code before the } \\
\text { product is loaded for delivery. The QR codes will be scanned (by the transporter) using a } \\
\text { scanner integrated in the smart logistics tool which has to be installed on the truck. }\end{array}$ \\
\hline Labeling rules & $\begin{array}{l}\text { A paper-based label of a rectangular shape with a length of } 150 \mathrm{~mm}-200 \mathrm{~mm} \text { and a width of } \\
100 \mathrm{~mm}-120 \mathrm{~mm} \text { has been implemented according to recommended rules under Section } 2.5 \text {. }\end{array}$ \\
\hline Label data elements & $\begin{array}{l}\text { Some information to be included in the biomass label: source of biomass (farm name), type of } \\
\text { the biomass (e.g., tree pruining, crop residues), seasonal efficiency (continuity of supply), } \\
\text { moisture content, ash content, date of harvest, and volumetric density. In this TS, these data } \\
\text { elements are included but not indicated on the label. The information is recorded and } \\
\text { regenerated via the QR code printed on the label. The company name, QR code, lot number, } \\
\text { and unique label code (assigned to the actor) are the key data elements indicated on the label } \\
\text { (see Section 2.5). }\end{array}$ \\
\hline
\end{tabular}

\subsection{Role and Responsibilities of Actors in the Pruning Biomass Supply Chain}

In order to make the TS more understandable, the role and responsibilities of major actors along the biomass logistics chain (see Figure 2) are described below [27].

Raw material supplier: In the case of pruning-to-energy initiatives, the raw material supplier is the farmer. This actor should provide information on 'origin and source' of the raw material, and this information will be documented and used throughout the supply chain. 
Solid biofuel producer: This could be either the farmer or another actor who receives raw biomass from the farmer and further processes the raw material. This actor also confirms whether the raw materials are provided according to the declaration given by the raw material supplier.

Solid biofuel trader: This actor should control the properties of received products and identify whether the products are provided according to the product declaration given by producer of the solid biofuel.

Solid biofuel consumer: This actor represents the end user, who should check the properties of the received product and identify whether the products are in compliance with the contract agreement between the trader and end consumer.

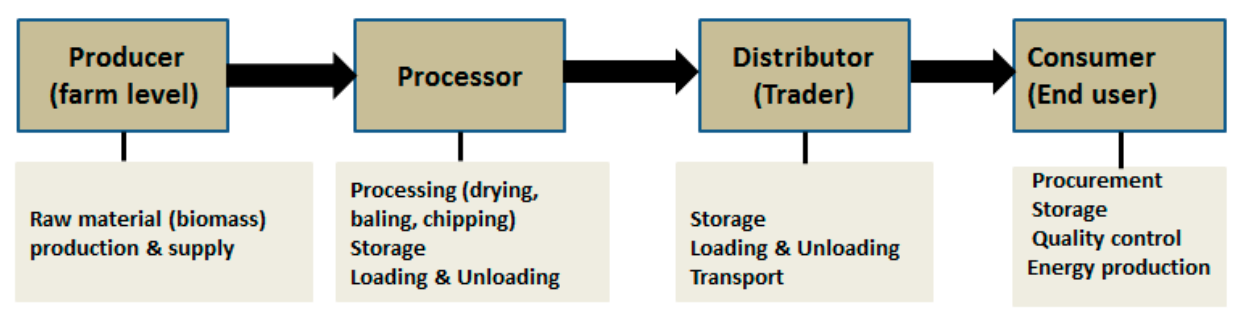

Figure 2. Example of agricultural pruning logistics chain (from farm to end-user) with traceability information flow.

\subsection{Assigning Product Delivery Identification Number}

There are three different codes used in this TS. These include the lot number, label code, and identification number for each product delivery.

Lot number (Lot no.): Each batch of product should be assigned a unique lot number. The lot number will also appear on label to be attached to the product. The lot number is used to track the product and it can be related to raw material used, processes and equipment used, testing performed, and personnel involved in producing a specific lot of product. In this labeling system, the lot number is assigned so that it indicates the year-month-day of production (or processing), if it is blended/mixed (B) or not blended/mixed (N), a two-digit sequential number, and rank (R) i.e., step in the value chain where the product is produced (or processed) and given a lot number.

Rank (R) along the chain: This refers to the stage along the supply chain (see Figure 2 and Table 2): (1) for fruit tree pruning and collection (farm level); (2) for the transport stage from farm to storage; (3) for the storage stage; and (4) for transport from storage to end user.

Table 2. Stages along the biomass logistics chain.

\begin{tabular}{|c|c|c|c|c|c|}
\hline $\begin{array}{l}\text { Logistics } \\
\text { Chain } \\
\text { Stage }\end{array}$ & Pruning Stage & Collection of Pruning & $\begin{array}{l}\text { Transport from } \\
\text { Farm to the } \\
\text { Storage }\end{array}$ & Storage Stage & $\begin{array}{l}\text { Transport from } \\
\text { Storage to End } \\
\text { User }\end{array}$ \\
\hline Rank R & & 1 & 2 & 3 & 4 \\
\hline $\begin{array}{l}\text { Activities in } \\
\text { labeling } \\
\text { system }\end{array}$ & $\begin{array}{l}\text { Documenting } \\
\text { data required } \\
\text { for traceability } \\
\text { (e.g., pruning } \\
\text { data, pictures) }\end{array}$ & $\begin{array}{c}\text { Documenting traceable } \\
\text { data required at } \\
\text { harvesting stage (e.g., } \\
\text { bales or chips } \\
\text { characteristics); } \\
\text { assigning lot number; } \\
\text { printing the label and } \\
\text { labeling the product }\end{array}$ & $\begin{array}{l}\text { Label reading } \\
\text { (scanning); } \\
\text { recording traceable } \\
\text { data using the } \\
\text { smart logistics tool; } \\
\text { quality and } \\
\text { quantity control }\end{array}$ & $\begin{array}{l}\text { Receiving } \\
\text { information } \\
\text { regarding new } \\
\text { product; quality } \\
\text { control; } \\
\text { preparing the } \\
\text { label and labeling } \\
\text { the product. }\end{array}$ & $\begin{array}{l}\text { Label reading; } \\
\text { recording data } \\
\text { during transport; } \\
\text { information } \\
\text { transfer; quality } \\
\text { control }\end{array}$ \\
\hline
\end{tabular}

For instance, if the lot number is 140424B01R1, 140424 refers to the year-month-date of production or processing (for 24 April 2014), B refers to blended/mixed product, 01 refers to the two-digit sequential number (this can be used to differentiate if there is change of biomass species, change of machinery, change of product type e.g., chip or bale), $\mathrm{R}$ refers to level in the value chain, and 1 refers 
to value of $\mathrm{R}$ (i.e., farm level or raw material producer). If the above product is not blended/mixture, its lot number will be 140424N01R1.

Label code: Each registered (as the user of the traceability system) actor (e.g., farmer, distributer etc.) of the supply chain will be given a specific label code. Based on the international standard organization (ISO), country codes are incorporated in this coding process. According to ISO 3166-1 alpha-3, country codes (e.g., FRA for France) are given in three letters [28]. In this TS, ISO 3166-1 alpha-3 is applied, because it has better connection between the country name and the code than ISO3166-1 alpha-2 code system. In this case, different actors such as the producers of raw materials (farmers), producers of solid biofuel (processors), and traders or distributors will be assigned specific labeling codes with a unique label number, as explained below.

(i) Farmer (raw material producer): Farmer is represented by $\mathrm{F}$ followed by the country code and a label number (three ciphers e.g., 001, 002, etc.) assigned to a specific farmer. For example, a farmer in France with label number 268, will be identified as FFRA268.

(ii) Processor (solid biofuel producer, e.g., storage stage): Processor is represented by P followed by the country code and label number assigned to it. For example, a processor in Germany with label number 157 will be identified as PDEU157. In general, for convenience, storage sites are considered under this category, whether there is further processing or not at the storage level.

(iii) Distributor: Distributor (or trader) is represented by D followed by the country code and label number. For example, a distributor in Germany assigned label number 257 can be identified as DDEU257.

(iv) Consumer: Consumer (end user) is represented by $\mathrm{C}$ followed by the country code and label number. For example, a consumer in Spain with label number 020 can be identified as CESP020.

Product delivery identification number: The unique identification number will be assigned to each delivery along the biomass supply chain. Such a unique number enables the user to trace back to each delivery along the whole chain from consumer to producer [20]. In this traceability system, this product delivery identification number will incorporate different codes identifying stages along the supply chain (see Figure 2 and Table 1 ) in addition to the lot number. For instance, if a product with the lot number indicated above (140424N01R1) is produced in France by a farmer with label number 268 , and shipped to a processer (or storage owner) in Germany with label number 157, the delivery system can have a unique identification number of FFRA268-PDEU157. This number should be used with the assigned lot number. For example, if lot number 140624B01R3 is processed by a processor in Germany with label number 157, and currently being handled by a distributor in Germany with label number 257, then the product can have a code PDEU157-DDEU257 to be used along with the lot number 140624B01R3 whenever product traceability is to be initiated.

\subsection{Traceability Information Flow}

In this TS, the detailed information flow can be obtained using the product delivery identification number explained above together with the product lot number. If there is a dealer (e.g., distributor) between the actor who produced the product and assigned the lot number and the current actor handling the product, all three actors should be indicated in the product delivery identification code. For instance, if the product delivery indicated above (PDEU157-DDEU257) is shipped to a second distributor in Germany with label number 388, then the complete code will be PDEU157DDEU257-DDEU388.

This TS starts with the actor that assigns the lot number and ends with the actor that handles the product (the step in the chain where the product exists). If the product is reprocessed (chipped, baled, or blended) then a new lot number will be assigned. Then the label code creation process in SLS will consider the new lot number for the traceability of the processed product. However, the processor who assigns the new lot number should document the previous lot number/s for continuation of information flow and to be used when required. 
Web-based information documentation and sharing center [29] has been employed for traceability information flow (Figure 1). This platform has been built in such a way that different registered actors (producers, traders, customers, and transporters) have access to it and record the information regarding their own pruning biomass products ready for trading or services to be provided. The platform assures the continuity of traceability information flow, which facilitates the inspection of the biomass supply chain and tracking/tracing of a particular item whenever required.

\subsection{Information on the Label}

On this label, it is mandatory to show the logo and the code (label number) of the producer or that of the registered trader (handling the product). Still, the complete identification with all codes from every step can be embedded in the QR code. Accordingly, the company name (label holder), lot number, label number (code with four letters and three-digit numbers) assigned to the label holder, and QR code will be indicated on the label (see Figure 3 and Table 3).

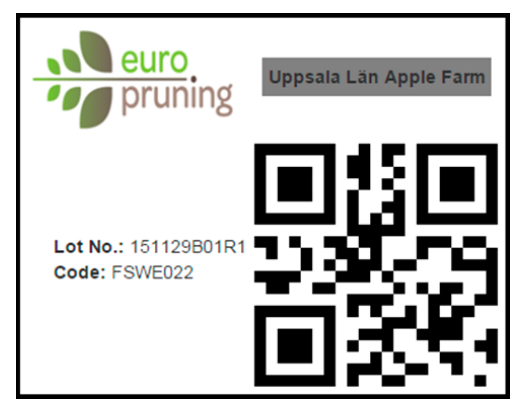

Figure 3. Example of printed label as integrated in the TS. It indicates a printed label for a biomass product with lot number 151129B01R1, label code of a farmer from Sweden: FSWE022, from a farm randomly named as Uppsala Lan Apple Farm in Sweden.

Table 3. Description of label elements.

\begin{tabular}{cr}
\hline Label Element & Description \\
\hline Shape & Rectangular shape: length of $150 \mathrm{~mm}-200 \mathrm{~mm}$; width of $100 \mathrm{~mm}-120 \mathrm{~mm}$ \\
Lot number & Times New Roman with minimum font size of 20 \\
Label code & Times New Roman with minimum font size of 20 \\
Company name & Times New Roman with minimum and maximum font sizes of 20 and 26, respectively \\
\hline
\end{tabular}

\subsection{Parameters to Be Traced}

This TS is integrated into the SLS tool. Some major parameters to be traced by this system are described in Table 4. The parameters indicated in Table 4 are important to control the quality of raw and preprocessed biomass materials. This increases the penetration of pruning residues in the market of solid biofuels. All actors across the logistic chain should provide the required information for the TS to keep track of fuel characteristics and maintain the required product quality. In this trading system, the major traded forms to be considered are bales and chips, for which the basic required characteristics are identified (see Tables 5 and 6). 
Table 4. Main traceable quality parameters to be implemented in the TS.

\begin{tabular}{|c|c|c|c|c|}
\hline \multicolumn{2}{|c|}{ Information } & $\begin{array}{l}\text { Raw Material } \\
\text { Producer }\end{array}$ & $\begin{array}{l}\text { Solid Biofuel } \\
\text { Producer }\end{array}$ & $\begin{array}{l}\text { Solid Biofuel } \\
\text { Trader }\end{array}$ \\
\hline \multicolumn{5}{|c|}{ Normative information (always to be stated) } \\
\hline \multirow{6}{*}{$\begin{array}{l}\text { Declaration of origin } \\
\text { and source }\end{array}$} & $\begin{array}{l}\text { Supplier (label code }{ }^{1} \text {, name, contact } \\
\text { information) }\end{array}$ & $\mathrm{X}$ & $\mathrm{X}$ & $\mathrm{X}$ \\
\hline & $\begin{array}{l}\text { Country/city of origin (country, farm } \\
\text { name and location) }\end{array}$ & $\mathrm{X}$ & $\mathrm{X}$ & $x$ \\
\hline & Contract number & $X$ & $x$ & $x$ \\
\hline & Lot number & $x$ & $x$ & $x$ \\
\hline & Quantity (tons) & $x$ & $\mathrm{x}$ & $x$ \\
\hline & $\begin{array}{l}\text { Origin and source according to } \\
\text { classification from standard } \\
\text { EN14961-1:2010 } \\
\text { 1.1.1 Whole trees without roots (and } \\
\text { variety name) } \\
\text { 1.1.7 Segregated wood from vineyards } \\
\text { and fruit orchards (and variety name) } \\
\text { 1.1.8 Blends and mixtures (variety names } \\
\text { and share of each as \% and/or farm } \\
\text { names (source) and share \%) }\end{array}$ & $\mathrm{X}$ & $\mathrm{X}$ & $x$ \\
\hline \multicolumn{2}{|c|}{ Traded form (chips, logs, branches, hog fuel, bale (round/cuboid)) } & & $\mathrm{X}$ & $X$ \\
\hline \multicolumn{2}{|c|}{ Particle size distribution * } & & $\mathrm{X}$ & $x$ \\
\hline \multicolumn{2}{|l|}{ Bale dimension * } & & $\mathrm{X}$ & $x$ \\
\hline \multicolumn{2}{|c|}{ Moisture content $(\mathrm{w}-\mathrm{\%}, \mathrm{ar})$} & & $\mathrm{x}$ & $x$ \\
\hline \multicolumn{2}{|l|}{ Ash content $(w-\%, d b)$} & & $\mathrm{x}$ & $x$ \\
\hline \multicolumn{2}{|c|}{ Density of bale $\left(\mathrm{kg} / \mathrm{m}^{3}\right.$, ar $)$} & $x$ & $x$ & $x$ \\
\hline \multicolumn{2}{|c|}{ Bulk density of chips $\left(\mathrm{kg} / \mathrm{m}^{3}\right.$, ar $)$} & & $\mathrm{X}$ & $x$ \\
\hline \multicolumn{2}{|c|}{ Chemically treated material (YES/NO) } & $\mathrm{X}$ & $x$ & $X$ \\
\hline \multicolumn{5}{|c|}{ Informative information } \\
\hline \multicolumn{2}{|l|}{ Picture } & $x$ & $\mathrm{X}$ & $x$ \\
\hline \multicolumn{2}{|c|}{ Crop characteristics: age, irrigation regime } & $\mathrm{X}$ & & \\
\hline \multicolumn{2}{|c|}{ Time from pruning to wood collection (days) } & $x$ & & \\
\hline $\begin{array}{l}\text { Storage stage: } \\
\text { Time (days) } \\
\text { Piled (dimensions)/s } \\
\text { Covered/uncovered } \\
\text { Material moved with }\end{array}$ & $\begin{array}{l}\text { read in small heaps } \\
\text { nechanical means (YES/NO) }\end{array}$ & $\begin{array}{l}X \\
X \\
X \\
X\end{array}$ & $\begin{array}{l}X \\
X \\
X \\
X\end{array}$ & $\begin{array}{l}X \\
X \\
X \\
X\end{array}$ \\
\hline \multicolumn{2}{|c|}{ Contamination with impurities (soil, plastic, metals) (YES/NO) } & $x$ & $x$ & $x$ \\
\hline \multicolumn{2}{|c|}{ Calorific value $\left(\mathrm{MJ} / \mathrm{kg}\right.$, ar) ${ }^{*}$} & & $x$ & $x$ \\
\hline
\end{tabular}

${ }^{1}$ label code is the label number assigned to the specific actor; ${ }^{*}$ when a farmer (raw material supply) acts as a biofuel producer, then the actor will be considered as a solid biofuel producer; $\mathrm{w}-\%$ : weight percentage; ar: as received (wet base); db: dry base.

Table 5. Recommended characteristics of major quality parameters [16].

\begin{tabular}{ccc}
\hline Parameter & Class & Recommended Characterstics \\
\hline Particle size distribution of chips & P45A & More than $75 \%$ of material between 8 and $45 \mathrm{~mm}$ \\
Bale size & D1 & 1.2 m diameter, $1.2 \mathrm{~m}$ length \\
Moisture content & M35 & Moisture content $\leq 35 \mathrm{w}-\%$ ar \\
Ash content & A3 & Ash content $\leq 3 \mathrm{w}-\% \mathrm{db}$ \\
\hline
\end{tabular}


Table 6. Particle size distribution classification for chips (by European Standard EN14961-1:2010 solid biofuels-Fuel specifications and classes)_Part 1: General requirements.

\begin{tabular}{cccc}
\hline Class & $\begin{array}{c}\text { Main Fraction } \\
\text { (at Least 75\%) } \mathbf{~ m m}\end{array}$ & $\begin{array}{c}\text { Fine Fraction } \\
(<3.15 \text { mm), w- } \%\end{array}$ & Coarse Fraction \\
\hline $\mathrm{P} 16 \mathrm{~A}$ & $3.15 \leq \mathrm{P} \leq 16 \mathrm{~mm}$ & $\leq 12 \%$ & $\leq 3 \%>16 \mathrm{~mm}$ and all $<31.5 \mathrm{~mm}$ \\
$\mathrm{P} 16 \mathrm{~B}$ & $3.15 \leq \mathrm{P} \leq 16 \mathrm{~mm}$ & $\leq 12 \%$ & $\leq 3 \%>45 \mathrm{~mm}$ and all $<120 \mathrm{~mm}$ \\
$\mathrm{P} 45 \mathrm{~A}$ & $8 \leq \mathrm{P} \leq 45 \mathrm{~mm}$ & $\leq 8 \%$ & $\leq 6 \%>63 \mathrm{~mm}, \mathrm{max} 3.5 \%>100 \mathrm{~mm}$, all $<120 \mathrm{~mm}$ \\
P45B & $8 \leq \mathrm{P} \leq 45 \mathrm{~mm}$ & $\leq 8 \%$ & $\leq 6 \%>63 \mathrm{~mm}$, max $3.5 \%>100 \mathrm{~mm}$, all $<350 \mathrm{~mm}$ \\
P63 & $8 \leq \mathrm{P} \leq 63 \mathrm{~mm}$ & $\leq 6 \%$ & $\leq 6 \%>100 \mathrm{~mm}$ and all $<350 \mathrm{~mm}$ \\
P100 & $16 \leq \mathrm{P} \leq 100 \mathrm{~mm}$ & $\leq 4 \%$ & $\leq 6 \%>200 \mathrm{~mm}$ and all $<350 \mathrm{~mm}$ \\
\hline
\end{tabular}

\section{Inspection}

Inspection is required in order to assure the biomass quality and sustainability of the system. In this case, the following inspections were recommended for the improved pruning biomass trading system.

(i) The first inspection could be conducted at the initial stage, when a biomass producer is interested in participating in the pruning biomass trading for energy production.

(ii) Inspection shall be done at defined time intervals (e.g., once in two years).

(iii) Unexpected inspection can be conducted upon demand if complaints have been received regarding the quality of product and/or process in producing and supplying pruning biomass for energy production.

This biomass trading system is expected to have the expertise to conduct such inspection or hire an accredited inspection body based on the defined biofuel quality parameters. A producer who is interested in joining the biomass trading system will receive a unique label code after fulfilling an initial inspection. In this case, an inspection is required regarding quality parameters considering raw material source and characteristics, type of storage for raw material and processed products, and the documentation of quality management according to recommended criteria (see Table 5).

The inspection is also important for ensuring the functionality of the TS so that any complaints from consumers or other actors can be addressed by pinpointing the logistics stage at which the problem occurred. This type of problem identification can be facilitated by examining the product delivery identification number (see Section 2.3) of the product, for which complaints are registered. The inspection takes into consideration the responsibilities and roles of each actor involved in the pruning biomass supply chain. The inspection also can consider whether the necessary training has been provided to employees (by the concerned actor) to improve the product and process quality.

This TS was integrated into an SLS and data collection and storage in a central database was conducted satisfactorily [6]. The stored data enables the tool to support product traceability and supply chain management very effectively. This enables the user to improve the performance of pruning biomass supply chain management and product traceability, leading to a reduction of product loss, increased coordination of resources utilization, as well as improved fuel quality. This biofuel traceability system was designed for agricultural pruning, but could also be adapted for any type of biomass-to-energy initiative to promote the efficient use of renewable energy sources [6]. In this way, it strengthens the efforts of promoting the development of local biomass supply chains for energy production with reduced environmental impact [30].

\section{Discussion}

Reducing the use of fossil fuel enables to limit its environmental impact due to related emissions. In Europe, energy policy issues focus on increasing the use of renewable energy sources $[1,31]$. Agricultural pruning contributes to such efforts. However, unlike the case of forestry biomass, the use agricultural pruning for energy generation needs technical support throughout the supply 
chain. For this, an effective logistics system plays a significant role in developing the sustainable use of prunings for biofuel. This enables the reduction of pruning biomass losses while increasing biofuel quality. From a study of a pruning logistics assessment considering the harvesting, storage, and transport of pruning biomass in some European countries (Germany, Spain, Italy, Poland, France, and Denmark), out of potential pruning biomass, the loss reaches up to $37 \%$ for chips and $32 \%$ for bales [31]. Similarly, the operational cost (at harvesting, storage, and transport stages) reaches up to $149 € / t$ and $123 € / t$ (wet base) when supplied in form of bales and chips, respectively [31].

Contamination of biomass with impurities such as soil, stones, and metals is one of the identified challenges related to pruning-based biofuel products. As a result, final consumers have less trust in the quality and quantity of pruning biomass supplies for their boilers [19,31]. Effective traceability and logistics systems enable to reduce such losses and costs of the production and supply of biofuel. The TS is also an important tool to control the quality of bales and chips. In particular, small-scale farmers who join the pruning-to-energy initiatives could benefit from such logistics and traceability systems that lead to the reduction of operational costs and increase of product quality control as well as increase of marketing opportunity.

The SLS increases the management efficiency. The information platform allows all registered users (farmers, traders, consumers, and transporters) to enter relevant data or to order the product they need to purchase. It enables the collection and storage of data from different actors in a single central database. The stored data and related information enable the system manager to efficiently conduct both product traceability and biofuel supply chain management. The SLS and TS designed in this paper can be tested further and upgraded to marketable standards promoting sustainable biomass development for renewable energy generation.

\section{Conclusions}

A traceability system (TS) is important for the quality control and effective management of the pruning biomass supply chain. It increases the sustainable utilization of renewable energy. Furthermore, it promotes the effective utilization of agricultural residues for energy generation. The developed TS is integrated into a smart logistics system (SLS) to improve the efficiency of a pruning biomass logistics system in the initiatives to promote the utilization of agricultural residues for renewable energy production.

The study has identified and defined the scope and general characteristics of the TS. The procedures and contents of the TS have been explained. The TS has been developed based on the biomass quality requirements to be used for energy production from chips and bales of pruning biomass. In addition, other standards describing solid fuel quality parameters such as the new European standards EN 14961-1, EN15234:1-2011, and EN14961-1:2010 have been considered.

In this TS, the detailed information flow can be obtained using a product's lot number, label code (to be assigned to each registered actor), and the product delivery identification number (to identify each product delivery chain). The product delivery identification number incorporates different label codes identifying stages along the supply chain and ensures continuity of traceability information flow. This continuity of information flow will also be augmented by the centralized information platform, which is part of the SLS, where the required information will be documented and investigated by the system manager.

In this pruning biomass trading system, the major traded forms are bales and chips with defined characteristics. Major traceable quality parameters include the declaration of origin and source of product, traded form, bale dimension, chips size distribution, moisture content, ash content, and density. However, chips particle size distribution, bale dimension, moisture content, and ash content are very relevant quality parameters from an energy point of view. Accordingly, appropriate inspections are recommended to assure biomass quality requirements and promote the sustainability of pruning biomass use. Further detailed studies are recommended to improve, implement, and evaluate this TS considering its economic and environmental implications for promoting the sustainable utilization of renewable energy resources. 
Acknowledgments: This study was part of the EuroPruning project (Development and implementation of a new and non-existent logistics chain for biomass from Pruning, Theme: KBB2012.1.2-01) which is partially financed by the European Commission's 7th Framework Programme for Research and Technological Innovation.

Author Contributions: Techane Bosona, Girma Gebresenbet, and Sven-Olof Olsson conceived and designed the TS. Sven-Olof Olsson participated in design and integration of the TS into smart logistics system. Techane Bosona and Girma Gebresenbet wrote the paper.

Conflicts of Interest: The authors declare no conflict of interest.

\section{References}

1. EUROSTAT. Renewable Energy Statistics. Available online: http://ec.europa.eu/eurostat/statisticsexplained/index.php/Renewable_energy_statistics (accessed on 8 January 2018).

2. Torquati, B.; Marino, D.; Venanzi, S.; Porceddu, P.; Chiorri, M. Using tree crop pruning residues for energy purposes: A spatial analysis and an evaluation of the economic and environmental sustainability. Biomass Bioenergy 2016, 95, 124-131. [CrossRef]

3. Blennow, K.; Persson, E.; Lindner, M.; Faias, S.P.; Hanewinkel, M. Forest owner motivations and attitudes towards supplying biomass for energy in Europe. Biomass Bioenergy 2014, 67, 223-230. [CrossRef]

4. Iakovou, E.; Karagiannidis, A.; Vlachos, D.; Toka, A.; Malamakis, A. Waste biomass-to-energy supply chain management: A critical synthesis. Waste Manag. 2010, 30, 1860-1870. [CrossRef] [PubMed]

5. Sustainability Criteria and Certification Systems for Biomass Production. Biomass Technology Group (BTG), Project Report, Project Number 1386, The Netherlands. 2008. Available online: http://www. compete-bioafrica.net/sustainability/sustainability_criteria_and_certification_systems.pdf (accessed on 20 November 2015).

6. Gebresenbet, G.; Bosona, T.; Olsson, S.-O.; Garcia, D. Smart System for the optimization of logistics performance of the pruning biomass value chain. Unpublished work. 2018.

7. Spugnoli, P.; Dainelli, R.; D'Avino, L.; Mazzoncini, M.; Lazzeri, L. Sustainability of sunflower cultivation for biodiesel production in Tuscany within the EU Renewable Energy Directive. Biosyst. Eng. 2012, 112, 49-55. [CrossRef]

8. Dabbene, F.; Gay, P.; Tortia, C. Traceability issues in food supply chain management: A review. Biosyst. Eng. 2013, 120, 65-80. [CrossRef]

9. Bosona, T.; Gebresenbet, G. Food traceability as an integral part of logistics management in food and agricultural supply chain. Food Control 2013, 33, 32-48. [CrossRef]

10. Produce Traceability Initiative Best Practices for Formatting Case Labels. Available online: http:// www.producetraceability.org/documents/Best_Practices_Case_Label-_010312_FINAL.pdf (accessed on 6 December 2017).

11. The Council of European Union. COUNCIL REGULATION (EC) No. 510/2006 of 20 March 2006 on the Protection of Geographical Indications and Designations of Origin for Agricultural Products and Foodstuffs. 2006. Available online: http:/ / eur-lex.europa.eu/legal-content/EN/TXT/?uri=celex:32006R0510 (accessed on 20 July 2015).

12. Folinas, D.; Manikas, I.; Manos, B. Traceability data management for food chains. Br. Food J. 2006, 108, 622-633. [CrossRef]

13. DENSO ADC. QR Code Essentials. 2011. Available online: http://www.nacs.org/LinkClick.aspx?fileticket= D1FpVAvvJuo\%3D\&tabid=1426\&mid=4802 (accessed on 28 August 2015).

14. Azuara, G.; Tornos, J.L.; Salazar, J.L. Improving RFID traceability systems with verifiable quality. Ind. Manag. Data Syst. 2012, 112, 340-359. [CrossRef]

15. Kelepouris, T.; Pramatari, K.; Doukidis, G. RFID-enabled traceability in the food supply chain. Ind. Manag. Data Syst. 2007, 107, 183-200. [CrossRef]

16. Caja, G.; Carne, S.; Salama, A.A.K.; Ait-Saidi, A.; Rojas-Olivares, M.A.; Rovai, M.; Capote, J.; Castro, N.; Arguello, A.; Ayadi, M.; et al. State-of-the-art of electronic identification techniques and applications in goats. Small Rumin. Res. 2014, 121, 42-50. [CrossRef]

17. Ruiz-Garcia, L.; Lunadei, L.; Barreiro, P.; Robla, J.I. A Review of Wireless Sensor Technologies and Applications in Agriculture and Food Industry: State of the Art and Current Trends. Sensors 2009, 9, 4728-4750. [CrossRef] [PubMed] 
18. Van Dam, J.; Junginger, M.; Faaij, A.; Jürgens, I.; Best, G.; Fritsche, U. Overview of recent developments in sustainable biomass certification. Biomass Bioenergy 2008, 32, 749-780. [CrossRef]

19. CIRCE and SLU. Description of the Biomass Specifications for the Value Chain. Project Report. 2013. Available online: file:/ / C:/Users/bosona/Downloads/EuroPruning_D2.1_Description\%20of\%20the\% 20biomass\%20specifications\%20for\%20the\%20value\%20chain\%20(1).pdf (accessed on 12 September 2017).

20. Biomasud. Handbook for the Quality Label of Domestic Solid Biofuels. 2012. Biomasud Project SOE/P2/E414. Available online: http://www.infocalidad.net/wp-content/uploads/130909_Manual_Sello_ Biomasud.pdf (accessed on 8 January 2018).

21. EN 14961-1: New European Pellets Standard. Available online: http://www.biointernational.ru/sites/ default/files / Alakangas_Pellet_standard_EN14961-1.pdf (accessed on 8 January 2018).

22. EN 15234-1:2011: Solid Biofuels. Fuel Quality Assurance. Available online: https://shop.bsigroup.com/ ProductDetail/ ?pid=000000000030219010 (accessed on 29 December 2017).

23. EN 14961-1: 2010—Solid Biofuels. Fuel Specifications and Classes, General Requirements. Available online: https: / / shop.bsigroup.com/SearchResults/?q=EN+14961-1\%3a2010 (accessed on 29 December 2017).

24. ISCC (2011): System Basics for the Certification of Sustainable Biomass and Bioenergy, ISCC 201 System Basics. Available online: https://www.iscc-system.org/wp-content/uploads/2017/02/ISCC_DE_201_ System-Basics.pdf (accessed on 29 December 2017).

25. Official Website of EuroPruning Project. Available online: http://www.europruning.eu/web/data/category. aspx?id=smartlogistics (accessed on 28 December 2017).

26. Bioenergy 2020. Proposal of a Product-Label for Small Scale Biomass Furnaces. 2013. Available online: http:/ /www.bioenergy2020.eu/files / publications/pdf/2010-09_Proposal_of_a_Label_for_small_ scale_Biomass_Frunaces.pdf (accessed on 28 October 2013).

27. Intelligent Energy Europe. Enhancing the Implementation of Quality and Sustainability Standards and Certification Schemes for Solid Biofuels (EIE/11/218). Solid Standards Project, Deliverable 2.1d, Wood Chip Module. 2011. Available online: file:// /C:/Users/bosona/Downloads/intelligent_energy_europe_-_ enhancing_the_implementation_of_quality_and_sustainability_standards_and_certification_schemes_for_ solid_biofuels_-_2014-07-17.pdf (accessed on 7 December 2017).

28. Country Code, ISO 3166-1 Alpha-3. Available online: http://unstats.un.org/unsd/tradekb/Print50347.aspx (accessed on 7 December 2017).

29. EuroPruning Application Website. Available online: http://europruning.mobitron.se/public/en (accessed on 25 November 2017).

30. Cavicchi, B.; Palmieri, S.; Odaldi, M. The Influence of Local Governance: Effects on the Sustainability of Bioenergy Innovation. Sustainability 2017, 9. [CrossRef]

31. EuroPruning Project Report on Logistics Chain and Knowledge Gaps of Biomass. SLU. 2016. Deliverable D5.1. Available online: http:/ / www.europruning.eu/web/data/category.aspx?id=smartlogistics (accessed on 30 December 2017).

(C) 2018 by the authors. Licensee MDPI, Basel, Switzerland. This article is an open access article distributed under the terms and conditions of the Creative Commons Attribution (CC BY) license (http://creativecommons.org/licenses/by/4.0/). 